\title{
The Current Situation of Zika Virus Infection: Is Turkey at Risk?
}

\section{Zika Virüs Enfeksiyonunda Güncel Durum: Türkiye Risk Altında mı?}

\author{
Tuğba Erat' ${ }^{1}$ Ergin Çiftçi' \\ ${ }^{1}$ Division of Pediatric Infection Diseases, Department of Pediatrics, Ankara University School of Medicine, Ankara, Turkey
}

\begin{abstract}
Zika virus infection is the first major infectious disease leading to human birth defects in 2015. Zika virus gives rise to babies microcephalic and threatens the health of children and future generations. Although there is no Zika virus infections reported yet in Turkey, the ability to travel to any far countries easily, causes the increasing the risk of Zika virus infection in Turkey. We know that Turkish people travel to outbreak areas from Turkey. This review describes the current understanding of the epidemiology, transmission, clinical characteristics, and diagnosis of Zika virus infection with scanning the recent literature.
\end{abstract}

Keywords: Guillain-Barré syndrome, microcephaly, pregnancy, zika virus

\section{Introduction}

The Zika virus infection is a clinical picture caused by the Zika virus, which is an RNA virus of the flaviviridae family. This virus has an envelope, has icosahedral capsid structure, and is a positive polarity single strand RNA virus (1). The Zika virus essentially infects humans and is transmitted by the bite of infected Aedes mosquitoes. In the Zika epidemics in South Africa the main vector was Aedes aegypti, and to a lesser degree Aedes albopictus. In the Yap Island and the French Polynesia epidemics, other sub-species, Aedes hensilli and Aedes polynesiensis were reported to be effective in transmission $(2,3)$.
Özet

Zika virüs enfeksiyonu, 2015 yılının anomalili bebek doğumlarının en önde gelen sebebi olmuştur. Zika virüsün bebekleri mikrosefalik kılması çocuk sağlığını ve gelecek nesilleri tehdit etmektedir. Türkiye'de henüz bildirilen Zika virüs enfeksiyonu olmamasına rağmen, ulaşım koşullarının kolaylaşması nedeni ile dünyanın her noktasına seyahat olanağı bulunması bu riski artırmaktadır. Türkiye'den de salgın olan bölgelere seyahatlerin olduğu bilinmektedir. Bu derlemenin amacı dünyanın geniş bir coğrafyasında salgın olarak görülmekte olan Zika virüs enfeksiyonunun epidemiyolojisi, tanısı, kliniği ve komplikasyonları hakkında son literatürler ışığında bilgi sunmaktır.

Anahtar Kelimeler: Gebelik, Guillain-Barré sendromu, mikrosefali, zika virüs

\section{Background}

Zika virus was first isolated in 1947 from the blood of a 766 Rhesus monkey in Zika forest, near Kampala in Uganda (4). A year later, the virus was recovered from the mosquitoes ( $A$. africanus) in the same forest. In that period, it was not known whether the Zika virus could cause a disease in humans. However, later in the sero-prevelance studies in different regions in Uganda, the Zika virus antibodies came out to be positive with a rate of $6.1 \%$, showing that it may cause disease in humans $(5,6)$. The first human case of Zika virus was six years later in Nigeria. A 10-year old girl had a feverish viral disease and the
Correspondence Address / Yazışma Adresi

Tuğba Erat

Ankara Üniversitesi Tıp Fakültesi, Çocuk Enfeksiyon Hastalıkları Bilim Dalı, Ankara-Türkiye

E-mail: tugbacancan84@hotmail.com
(C) Copyright 2017 by Pediatric Infectious Diseases Society-Available online at www.cocukenfeksiyon.org

OTelif Hakkı 2017 Çocuk Enfeksiyon Hastalıkları Derneği -Makale metnine www.cocukenfeksiyon.org web sayfasından ulaşılabilir 
Zika virus was detected in her serum (7). 54 years after the first symptomatic Zika virus infection in a human, in the second half of the $20^{\text {th }}$ century and the first half of the $21^{\text {st }}$ century, about 13 sporadic human cases were reported in Africa and in South and Southeast Asia (8-12). The first known Zika virus epidemics was reported in 2007 in the Yap Island, Micronesia Federal State. It was detected that in this epidemics, of the 6892 individuals over 3 -years old residing in the Yap Island, 5005, that is $73 \%$ was infected with the Zika virus. The number of cases verified 49 and there are cases within every age group. In this first epidemics, the rate of being infected was $73 \%$, and the rate of symptomatic disease was $18 \%$, and there was no hospitalization and no mortality. That is, one individual in five infected with the Zika virus was reported to have symptomatic Zika virus infection (13). Following the Yap Island epidemics, other epidemics we reported, in the French Polynesia in 2013, in the Pacific Islands in 2014, and in Brazil in 2015 (14-16). In the Zika virus epidemics starting in Brazil in February 2015, it has been estimated that 1.3 million individuals were infected within 11 months. In October 2015, a Zika virus case was reported in America other than Brazil, in Colombia, and since March 2016 the Zika virus has been reported in 33 countries of America. According to the data from the World Health Organization, between 2007 and February 2016, a Zika virus case has been reported in 59 countries (Figure 1). The first case in Europe was reported in 2013 in a German citizen who had visited Tailand, and also sporadic cases has been reported in Italy and France (17-19).

\section{Transmission}

The Zika virus infection is transmitted to humans essentially by infected mosquitoes (A. aegypti, $A$. albopictus). Mosquitoes are infecting when sucking blood from humans with Zika virus viremia and transmit the virus to healthy individuals when sucking blood from them. Mosquitoes of the Aedes species lay their eggs at the edges of stagnant water. The eggs remain viable especially at the edges of stagnant water without hatching for about a few days to a few months. Adult mosquitoes of the Aedes species may live outdoors and indoors. They prefer to bite humans in daytime $(20,26)$.

That the rate of microcephaly in Brazil in 2015 increased compared to previous years and that in these regions in the same period there was Zika virus infection epidemics suggests a relationship between the Zika virus and microcephaly. It was shown in Brazil that the Zika virus was transmitted intrauterine and caused congenital abnormalities, when the amnion fluid of two fetuses, with the mothers having viral infection during pregnancy, were found Zika virus PCR positive. Perinatal transmission and sexual transmission are other ways of transmission $(26,27)$.

\section{Clinical Course}

The hatching period of the Zika virus infection is considered to be seven days generally, however, it may extend up to 12 days. In the Yap Island epidemics, the first reported epidemics, the most frequent symptoms were fever, rash, conjunctivitis and arthralgia. Fever rarely rises up to $39-40^{\circ} \mathrm{C}$ and is subfebrile. The rash is itchy and has macropapular characteristics. Conjunctivitis is nonpurulent. In general, the symptoms continue for one week, which is the virilemia duration. The duration of the arthralgia is the one with the longest symptom and may continue for two weeks or more other findings are vomiting, head ache, retroorbital ache, and myalgia. There may be localized or generalized lymphadenopathy $(13,28)$.

\section{Diagnosis}

For Zika virus infection diagnosis, firstly the patient must have been residing in or must have traveled to the region where there is an epidemic. Diagnosis is decided upon clinically and by laboratory tests. The laboratory tests may search for viral RNA using Zika virus specific Immunoglobulin M (IgM), neutralizing antibody and reverse transcriptase polymerase chain reaction (RT-PCR). IgM becomes positive after four days and stays positive for 12 weeks. It is a high probability that cross-reactions occur since in a region where there is an epidemic, the Dengue virus and Chikungunya virus infections are frequent and there is seropositivity. The yellow fever vaccine can also cause a cross-reaction. The Plaque reduction neutralization test (PNRT) is a diagnostic test useful to detect Zika virus specific antibodies and to eliminate the complexities caused by false positives due to cross-reaction. If patients with Zika virus infection symptoms refer to the hospital within the onset of symptoms to the first week, the viral RNA can be detected by RT-PCR (29-31). In Zika virus diagnostic algorithms, firstly, the Dengue virus and Chikungunya virus infections must be excluded.

It has been shown that the Zika virus can be found in saliva, semen and urine as well as serum and plasma. The Zika virus is positive for five days in saliva and serum PCR on the average and may be detected as positive up to eight days. In urine it is basically positive for 10 days and remain positive for up to 30 days; in the ejaculate fluid it has been reported that the Zika virus may be PCR positive up to 62 days (30-32).

\section{Differential Diagnosis}

In the differential diagnosis of the Zika virus, there are many infection diseases with fever and rash. Examples of such diseases are measles, rubella, enteroviruses, adenovirus, parvovirus, Rickettsia infection, leptospirosis and malaria. However, the first thing that leaps into the mind in differential diagnosis are the Dengue and Chinkungunya viruses since these occur as epidemics in the same geography, since they are carried by the same vector and since their symptomatologies are highly 
similar. The Dengue virus may manifest three clinical presentations: Dengue fever, Dengue hemorrhagic fever and Dengue hemorrhagic shock. There may be limited findings such as fever, thrombocytopenia and there may be findings threatening life such as hemorrhage, shock, organ failure. In Chikungunya infection fever, arthralgia, lynmphopenia are more outstanding (32-34).

\section{Treatment}

The treatment for the Zika virus infection is supportive treatment such as bedrest, analgesics, and antipyretics. There is no specific antiviral treatment or vaccine. The point to be taken care is not to prescribe non-steroid anti-inflammatory drugs or aspirin without first excluding the Dengue virus infection since there will be risk of hemorrhage $(26,35)$.

\section{Protection}

The main method for protection from Zika virus infection is to control vector control since there is no vaccine or antiviral treatment. To take precautions against mosquito bites one must wear clothes that do not leave open places on the body and bed nets, fly nets and mosquito repellents must be used. Yellow bubs should be used because of their repellent effect; care must be taken that there are no pools or stagnant water accumulations. Stopovers using air conditioning for ventilation should be chosen. Prevention of mosquito bites within the period of the onset symptoms and the first week, which is the viremic period of the patients with Zika virus infection will prevent transmittance between humans.

The most serious complication known currently of the Zika virus are microcephaly and neurological development disor- ders; thus, pregnant women or those who are planning pregnancy must be warned against travel to epidemic regions (36).

\section{The Relationship Between the Zika virus and the Guillain-Barré syndrome}

The first Guillain-Barré syndrome case developing in connection with a Zika virus infection was reported in 2013, during the French Polynesia epidemic. A forty year old female patient was diagnosed with the Guillain-Barré syndrome on the seventh day of the Zika virus infection upon findings such as tetraparasis in the lower extremities, bilateral facial paralysis, reduction in deep tendon reflexes; she was monitored in the intensive care unit due to ventricular tachycardia and orthostatic hypertension. On the $28^{\text {th }}$ day, Zika virus plaque reduction neutralization test (PNRT) was carried out and was found to be positive (37). In the 2013-2014 French Polynesia epidemic, there were 42 cases of Guillain-Barré syndrome in the six-month epidemic, which had been on the average three to five cases yearly in the country. These findings suggested a relationship between the Zika virus and the Guillain-Barré syndrome (38). The World Health Organization reported increase in Guillain-Barré syndrome associated with Zika virus in a total of 13 countries based on April 2016 data (39).

\section{Zika virus Infection in Pregnancy}

The Zika virus infection is one of the most important factor abnormal deliveries in the last year in regions of epidemics. The Zika virus has been included in the TORCH group infections, which are congenital infections. Thus, the association between the Zika virus and pregnancy has been widely considered. Looking at previous years, while the birth of babies with micro-

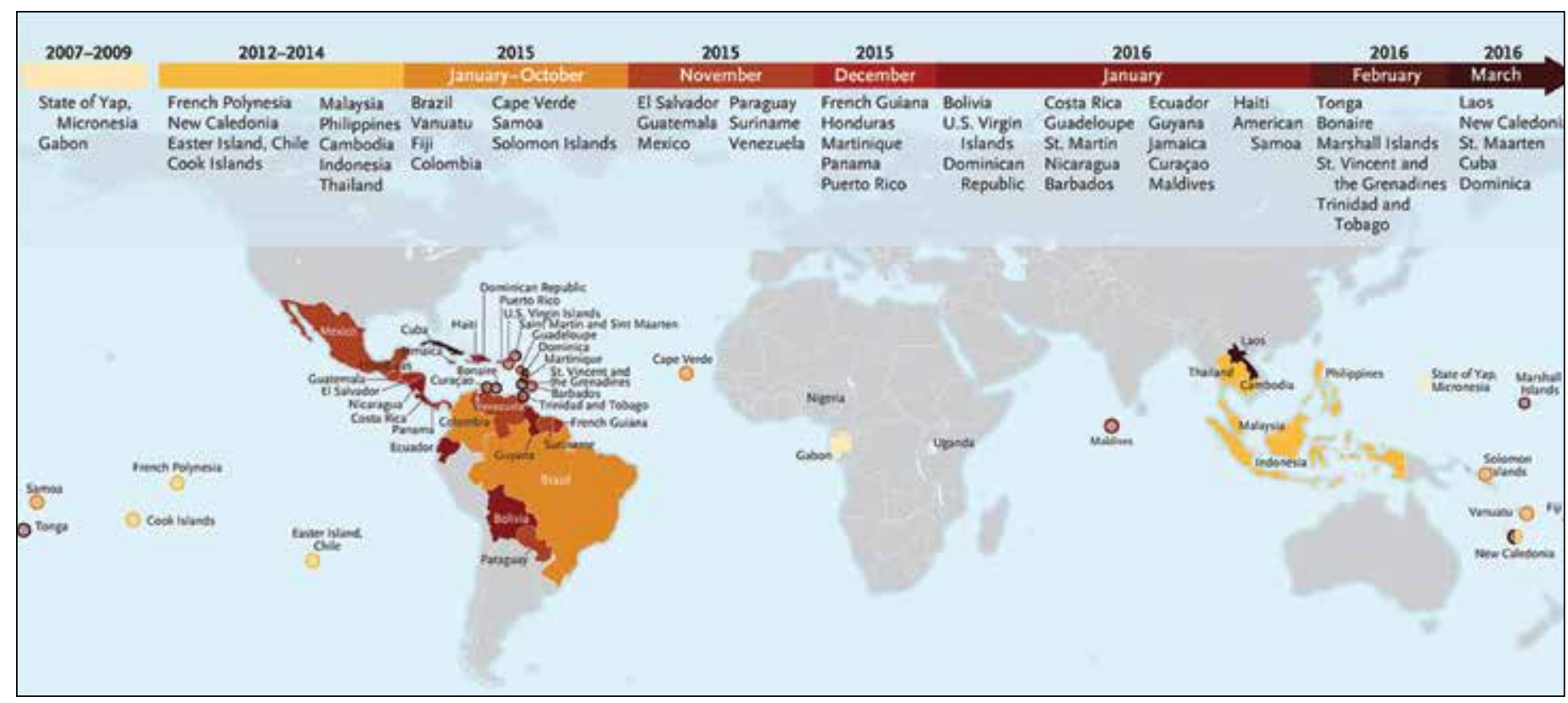

Figure 1. Current status in Zika virus epidemics (26). 
cephaly in Brazil was on the average 163 cases/year, there were 4000 cases/year in 2015. Concomitantly with the increase in the rate of microcephalic babies, there was Zika virus infection epidemic in these regions of Brazil, which suggests an association between the Zika virus and the microcephalic babies. This association was demonstrated by the fact that the head circumferences of the fetuses were below - 2.6 and -3.1 SD in the two pregnant women in the ultrasound and that the amnion fluids were Zika virus positive by RT-PCR. The fetal ultrasounds of thee two cases showed that besides microcephaly, there could be abnormalities such as calcifications in the cerebral parenchyma, vermis, corpus callosum dysgenesis, brain atrophy, cystic asymmetric ventriculomegaly, absence of thalamus, this brain sten and pons. Furthermore, eye abnormalities, disorder and calcifications in the normal anatomic development of the eye were detected. It has been shown that the brain tissue or the placenta of the babies who has microcephaly or various brain anomalies and who have died after delivery, were Zika virus viral antigen and RNA positive. In another study, 42 pregnant women who had Zika virus infection at pregnancy or who were Zika virus PCR positive were followed up and abnormalities were detected by ultrasound in 12 of them (29\%). In addition to the previously known abnormalities, intrauterine development retardation, placental failure and oligohydroamniosis were also detected. In addition to the belief that the Zika virus infection in the first trimester caused abnormal infant births based on previous studies, it was seen that the Zika virus infection in the $22^{\text {nd }}-26^{\text {th }}$ weeks of the pregnancy led to microcephaly $(21-23,28)$. Currently, there is no adequate information on the incidence of the Zika virus infection or on the severity of it in pregnant women. Another unknown issue is the delivery proportion of abnormal births by pregnant women who had Zika virus infection. The CDC guidelines recommend that the pregnant women who had Zika virus infection in pregnancy or who live in regions of epidemic are followed up and if a fetus with abnormally is detected, aminiosynthesis is carried out. It is recommended that the infants of the mothers who had Zika virus infection in pregnancy are followed up in the long term and newly detected findings are notified (40). Today, the most important prevention method is not traveling to the regions of epidemic for pregnant women or for women having pregnancy plans. As stated in CDC guidelines, pregnant women and those who have pregnancy plans must be warned that sexual transmission also affects the development of the fetus since the Zika virus is detected in the ejaculate fluid up to 62 days.

\section{The Zika virus in Turkey}

Although there is no notified cases of the Zika virus infection in Turkey, that facilitated transportation and travel to anywhere in the world is increasing this risk. It is known that significant numbers of travels are being made to the regions of epidem- ic from Turkey. For instance, many people from Turkey participated the Rio Carnival programme in Brazil in 2016. It is known that many people will visit Rio de Janeiro, which is the second biggest city of Brazil and will be the home to the 2016 Summer Olympics in August. The Zika virus infection must be considered in patients showing the symptoms within two weeks after visiting such regions. Although it gives rise to concerns that the mosquitoes of the Aedes species have been detected in Turkey, it was found that they do not carry the Zika virus. The Turkish Public Health Institution a guide in February 2016 on informing on the Zika virus and on case management. The patients suspected of the Zika virus infection in Turkey must be communicated and the the tests must be submitted to them. The Turkish Public Health Institution carries out Zika virus PCR in serology and tissue.

Peer- review: Externally peer-reviewed.

Author Contributions: Concept - TE; Design - TE, EÇ; Supervision - EÇ; Data Collection and/or Processing - TE, EÇ; Analysis and/or Interpretation - TE, EÇ; Literature Review - TE, EÇ; Writing - TE; Critical Review - TE

Conflict of Interest: No conflict of interest was declared by the authors.

Financial Disclosure: The authors declared that this study has received no financial support.

\section{References}

1. Kuno G, Chang GJ. Full-length sequencing and genomic characterization of Bagaza, Kedougou, and zika viruses. Arch Virol 2007;152:687-96.

2. Ledermann JP, Guillaumot L, Yug L, et al. Aedes hensilli as a potential vector of chikungunya and zika viruses. PLoS NegI Trop Dis 2014;8:e3188.

3. Musso D, Nilles EJ, Cao-Lormeau VM. Rapid spread of emerging zika virus in the Pacific area. Clin Microbiol Infect 2014;20:0595-6.

4. Dick GW, Kitchen SF, Haddow AJ. Zika virus. I. Isolations and serological specificity. Trans R Soc Trop Med Hyg 1952;46:509-20.

5. Dick GW. Zika virus. II. Pathogenicity and physical properties. Trans $R$ Soc Trop Med Hyg 1952;46:521-34.

6. Dick GW. Epidemiological notes on some viruses isolated in Uganda; Yellow fever, Rift Valley fever, Bwamba fever, West Nile, Mengo, Semliki forest, Bunyamwera, Ntaya, Uganda S and Zika viruses. Trans R Soc Trop Med Hyg 1953;47:13-48.

7. Macnamara FN. Zika virus: a report on three cases of human infection during an epidemic of jaundice in Nigeria. Trans $R$ Soc Trop Med Hyg 1954;48:139-45.

8. Smithburn KC. Neutralizing antibodies against arthropod-borne viruses in the sera of long-time residents of Malaya and Borneo. Am J Hyg 1954;59:157-63.

9. Hammon WM, Schrack WD, Sather GE. Serological survey for a arthropod borne virus infections in the Philippines. Am J Trop Med Hyg 1958;7:323-8.

10. Pond WL. Arthropod-Borne Virus Antibodies in Sera from Residents of South-East Asia. Trans R Soc Trop Med Hyg 1963;57:364-71. 
11. Fagbami AH. Zika virus infections in Nigeria: virological and seroepidemiological investigations in Oyo State. J Hyg (Lond) 1979:83:213-9.

12. Olson JG, Ksiazek TG, Suhandiman, Triwibowo. Zika virus, a cause offever in Central Java, Indonesia. Trans R Soc Trop Med Hyg 1981;75:389-93.

13. Duffy MR, Chen IH, Hancock WI, et al. Zlka virus outbreak on Yap Island, Federated States of Micronesia. N Engl J Med 2009;360:2536-43.

14. Tognarelli J, Ulloa S, Villagra E, et al. A report on the outbreak of Zika virus on Easter Island, South Pacific, 2014. Arch Virol 2016;161:665-8.

15. Campos GS, Bandeira AC, Sardi SI. Zika virus outbreak, Bahia, Brazil. Emerg Infect Dis 2015;21:1885-6.

16. Jouannic JM, Friszer S, Leparc-Goffart I, Garel C, Eyrolle-Guignot D. Zika virus infection in French Polynesia. Lancet 2016;387:1051-2.

17. Zika virus spreads to new areas - Region of the Americas, May 2015-January 2016. MMWR Morb Mortal Wkly Rep 2016;65:55-8.

18. Zika virus microcephaly and Guillain-Barré syndrome. Geneva: World Health Organization, March 17, 2016.

19. Tappe D, Rissland J, Gabriel M, et al. First case of laboratory-confirmed Zika virus infection imported into Europe, November 2013. Euro Surveill. 2014;19.

20. Surveillance and Control of Aedes aegypti and Aedes albopictus in the United States.

21. Oliveira Melo AS, Malinger G, Ximenes R, Szejnfeld PO, Alves Sampaio S, Bispo de Filippis AM. Zika virus intrauterine infection causes fetal brain abnormality and microcephaly: tip of the iceberg? Ultrasound Obstet Gynecol 2016;47:6-7.

2L. Meaney-Delman D, Hills SL, Williams C, et al. Zlka virus Infection among U.S. pregnant travelers - August 2015-February 2016. MMWR Morb Mortal Wkly Rep 2016;65:211-4.

23. Notes from the field: evidence of Zika virus infection in brain and placental tissues from two congenitally infected newborns and two fetal losses--Brazil, 2015. MMWR Morb Mortal Wkly Rep 2016;65:159-60.

24. Besnard M, Lastere S, Teissier A, Cao-Lormeau V, Musso D. Evidence of perinatal transmission of Zika virus, French Polynesia, December 2013 and February 2014. Euro Surveill 2014;19.

25. Foy BD, KobylinskI KC, Chilson Foy JL, et al. Probable non-vector-borne transmission of Zika virus, Colorado, USA. Emerg Infect Dis 2011;17:8802.
26. Lyle RP, Denise JJ, Ann MP, Margaret AH. Zika virus. $N$ Engl J Med 2016;374:1552-63.

27. Dupont-Rouzeyrol $M$, Biron A, O'Connor O, Huguon E, Descloux E. Infectious Zika viral particles in breastmilk. Lancet 2016;387:1051.

28. Brasil P, Pereira JPJr, Moreira ME, et al. Zika virus infection in pregnant women in Rio de Janeiro. NEngl J Med 2016:375:2321-34.

29. Lanciotti RS, Kosoy OL, Laven JJ, et al. Genetic and serologic properties of Zika virus associated with an epidemic, Yap State, Micronesia, 2007. Emerg Infect Dis 2008;14:1232-9.

30. Musso D, Roche C, Nhan TX, Robin E, Teissier A, Cao-Lormeau VM. Detection of Zika virus in saliva. J Clin Virol 2015;68:53-5.

31. Gourinat AC, O'Connor O, Calvez E, Goarant C, Dupont-Rouzeyrol M. Detection of Zika virus in urine. Emerg Infect Dis 2015;21:84-6.

32. Basarab M, Bowman C, Aarons EJ, Cropley I. Zika virus. BMJ 2016;352:i1049.

33. Kelser EA. Meet dengue's cousin, Zika. Microbes Infect 2016;18:163-6.

34. World Health Organization. Zika Virus Disease, Interim case definition. 2016 12 February. Available from: http://www.who.int/csr/disease/zika/casedefinition/en/

35. Malone RW, Homan J, Callahan $W$, et al; Zika Response Working Group. Zika Virus: Medical Countermeasure Development Challenges. PLoS Negl Trop Dis 2016;10:e0004530.

6. Centers for Disease Control and Prevention. Zika Virus. Available from http://www.cdc.gov/zika/prevention/index.html

37. Uehier E, Watrin L, Larre P, et al. Zika virus Infection complicated by Gutlain-Barré syndrome--case report, French Polynesia, December 2013. Euro Surveill 2014;19.

38. Cao-Lormeau VM, Blake A, Mons S, et al. Guillain-Barré Syndrome out break associated with Zika virus infection in French Polynesia: a case-con trol study. Lancet 2016;387:1531-9.

39. WHO. ZIka VIrus stuation reports. Avallable from: hitp:T/WWW.Who.Int emergencies/zika-virus/situation-report/28-april-2016/en/

fo. Cencers for Disease Control and Prevention. http.t/www.cac.gov/mmwr volumes/65/wr/mm6502e1.htm $\neq F 1$ down. 